\title{
Uji Efektivitas Ekstrak Biji Kakao (Theobroma Cacao L.) Sebagai Antibakteri Dalam Berbagai Konsentrasi pada Streptococcus Pyogenes
}

Dame J Pohan, Angela P Kakerissa, Evy S Arodes

${ }^{1}$ Departemen Mikrobiologi Fakultas Kedokteran, Universitas Kristen Indonesia, Jakarta-Indonesia

\begin{abstract}
ABSTRAK
Biji kakao adalah buah yang dikenal sejak dahulu sebagai buah yang memiliki peran penting dalam bidang kesehatan, salah satunya sebagai antibakteri. Biji kakao mengandung senyawa flavonoid, tanin, dan alkaloid yang memiliki efek antimikroba. Tujuan penelitian ini untuk mengetahui efektivitas ekstrak biji kakao terhadap bakteri Streptococcus pyogenes, yaitu dengan cara mengukur zona hambat menggunakan metode difusi KirbyBeuer dengan konsentrasi ekstrak biji kakao 20\%, 40\%, 60\%, 80\% dan 100\%. Hasil penelitian menunjukan ekstrak biji kakao dapat efektif memberikan efek antibakteri mulai dari konsentrasi terkecil $20 \%$ dengan ratarata diameter zona hambat $8.07 \mathrm{~mm}$ sampai konsentrasi terbesar 100\% dengan rata-rata diameter zona hambat $10.98 \mathrm{~mm}$. Sedangkan rata-rata diameter zona hambat antibiotik Ampisilin sebagai kontrol (+) lebih besar dari konsentrasi ekstrak biji kakao. Berdasarkan data tersebut dapat disimpulkan ekstrak biji kakao dapat efektif menghambat pertumbuhan bakteri Streptococcus pyogenes
\end{abstract}

Kata kunci: Kirby-Bauer, Zona Hambat, Antimikroba

\section{Effectiveness Test of Cocoa Seed (Theobroma Cacao L.) Extract as an Antibacterial Ii Various Concentrations on Streptococcus pyogenes}

\begin{abstract}
Cocoa Seed is a fruit that has been known for a long time as a fruit that has an important role in health, which is as an antibacterial. Cocoa seeds contain a high composition of flavonoids, tannins, and alkaloids which have antimicrobial effects. The aim of this research was to study the effect of cocoa seed extracts against Streptococcus pyogenes, by measuring the inhibition zone using the Kirby-Bauer diffusion method using concentrations of cocoa seed extract $20 \%, 40 \%, 60 \%, 80 \%$ and $100 \%$. The results showed that chocolate seed extract could effectively provide an antibacterial effect ranging from a concentration of $20 \%$ with an average diameter of inhibition zone of $8.07 \mathrm{~mm}$ to the largest concentration of $100 \%$ with an average zone diameter of inhibition of $10.98 \mathrm{~mm}$. While the average diameter of the inhibitory zone of antibiotic ampicillin as a control $(+)$ is greater than the concentration of cocoa seed extract. Based on these data, it can be concluded that cocoa seed extract can effectively inhibit the growth of Streptococcus pyogenes.
\end{abstract}

Keywords: Kirby-Bauer, Inhibitory zone, Antimicrobial

*ESA: Penulis Koresponden; E-mail: evy.ard88@gmail.com 


\section{PENDAHULUAN}

Indonesia merupakan negara kepulauan dengan seribu pulau, yang mempunyai keanekaragaman dan kekhasan ekosistem yang luar biasa. Indonesia juga merupakan negara yang memiliki keanekaragaman hayati karena merupakan gabungan dari dua benua, yaitu Asia dan Australia. Potensi luar biasa yang dimiliki Indonesia ini membutuhkan pemberdayaan yang lebih intensif untuk melakukan penelitian di bidang tanaman obat sebagai pengobatan alternatif lain di bidang kesehatan. ${ }^{1,2}$

Masyarakat akhir-akhir ini lebih sering memilih produk-produk di pasaran yang berlabel herbal dengan alasan lebih aman untuk kesehatan, efek samping relatif sedikit, dan dianggap lebih murah dari segi ekonomi. Sudah banyak penelitian di Indonesia yang menganalisis tanaman-tanaman yang ada di sekitar kita untuk dijadikan sebagai obat herbal. ${ }^{3}$ salah satu diantaranya adalah kakao buah kakao (Theobroma cacao). ${ }^{4}$

Buah kakao merupakan salah satu komoditas unggulan di Indonesia yang telah dikenal sejak tahun 1560. Negara Indonesia merupakan penghasil kakao terbesar ketiga setelah Ghana dan Pantai Gading. Selain itu, komoditas kakao merupakan komoditas penghasil devisa negara nomor tiga setelah kelapa sawit dan karet. ${ }^{5}$

Peneliti dari National Institute of Public Health and Environtment di Bilthoven, Belanda, tahun 1999 telah melakukan penapisan fitokimia terhadap bahan alami buah kakao. Kandungan fitokimia yang terkandung pada kakao adalah katekin yang merupakan golongan flavonoid dan merupakan salah satu antioksidan terkuat. ${ }^{6}$

Pada tahun 2012, Mulyatni et $a .^{7}$ membuktikan bahwa flavonoid yang terkandung dalam buah kakao memiliki aktivitas antibakteri terhadap bakteri Escherichia coli, Bacillus subtilis, dan Staphylococcus aureus. Ekstrak biji kakao juga terbukti memiliki antibakteri dalam menghambat kuman Streptococcus mutans berdasarkan penelitian Medan Yumas (2017), yang merupakan salah satu penyebab utama karies gigi. ${ }^{8}$

Centers for Disease Control and Prevention menyatakan bahwa bakteri Streptococcus pyogenes (S. pyogenes) merupakan salah satu penyebab penyakit menular yang paling mengancam jiwa. Penyakit yang paling sering disebabkan oleh bakteri ini adalah faringitis akut dan dapat berkomplikasi menjadi scarlet fever seperti wabah yang terjadi pada Hong Kong 2011. Beberapa penelitian menunjukan wabah tersebut yang disebabkan oleh bakteri $S$. pyogenes sudah memiliki resistensi terhadap antibiotik Makrolid dan Tetrasiklin. ${ }^{10-12}$

Kandungan fitokimia dari biji kakao sudah terbukti mempunyai efek antibakteri dan kemampuan $S$. pyogenes yang dapat resisten terhadap beberapa antibiotik membuat penulis tertarik untuk melakukan penelitian yang bertujuan untuk mengetahui aktivitas antibakteri biji kakao terhadap bakteri $S$. pyogenes penyebab scarlet fever.

\section{Bahan dan Cara}

Penelitian ini bersifat deskriptif-eksperimental untuk menguji efek bakterisida ekstrak biji kakao terhadap $S$. pyogenes menggunakan metode Kirby-Bauer. ${ }^{9}$ Analisis dan pengolahan data menggunakan uji One Way Anova. Uji analisis ini bertujuan untuk menganalisis dua variabel, yaitu variabel terikat dan variabel bebas untuk mengetahui ada tidaknya pengaruh pemberian ekstrak biji kakao (Theobroma cacao) terhadap pertumbuhan bakteri S. pyogenes.

\section{Prosedur penelitian}

Persiapan Biji Kakao untuk Ekstraksi 
Biji Kakao matang dicuci dan dikeringkan dengan suhu ruangan selama dua hari setelah itu dikeringkan dalam oven pada suhu $100^{\circ} \mathrm{C}$ selama tiga hari. Bahan yang sudah kering digiling menggunakan mesin penggiling atau blender hingga diperoleh serbuk yang homogen.

\section{Ekstraksi Buah Biji Kakao dengan Pelarut Organik}

Serbuk biji kakao diekstraksi dengan cara Maserasi menggunakan pelarut etanol proanalisis dengan perbandingan antara simplisia serbuk dan etanol adalah 1:4. Maserasi di lakukan selama tiga hari dengan pergantian etanol setiap hari. ${ }^{8}$

Sebanyak 100 g serbuk biji kakao direndam dengan $400 \mathrm{~mL}$ etanol di dalam Erlenmeyer. Perendaman dilakukan dalam suhu ruang pada shaker dengan kecepatan $120 \mathrm{rpm}$ secara kontinu selama 24 jam. Penyaringan dilakukan dengan kertas saring Whatman berdiameter $90 \mathrm{~mm}$, sehingga diperoleh maserat. Pelarut (etanol) dalam maserat diuapkan menggunakan rotary evaporator hingga diperoleh ekstrak pekat berbentuk pasta. Ekstrak tersebut ditimbang dan disimpan dalam wadah eppendorf sebelum digunakan sebagai bahan uji.

\section{Uji Aktivitas Antibakteri}

Uji aktivitas antibakteri dilakukan dengan metode difusi Kirby-Bauer. Sebanyak $5 \mathrm{~mL}$ suspensi bakteri uji S. pyogenes yang telah diukur kekeruhan sesuai standard 0,5 McFarland dimasukkan ke dalam cawan petri dan ditambahkan Agar Mueller Hinton (MHA). Dibuat 6 lubang pada media MHA dengan jarak $\pm 20 \mathrm{~mm}$.

Sebanyak $50 \mu \mathrm{L}$ ekstrak dengan pengenceran $20 \%, 40 \%, 60 \%$, $80 \%$, dan $100 \%$ diteteskan ke masing-masing lubang. Kertas cakram kosong dicelupkan dalam akuuades steril digunakan sebagai kontrol negatif dan cakram antibiotik Ampisilin digunakan sebagai kontrol positif. Isolat uji kemudian diinkubasi pada suhu $37^{\circ} \mathrm{C}$ selama 24 jam, setelah itu dilakukan pengamatan dan dihitung diameter zona bening yang terbentuk menggunakan jangka sorong.

\section{Hasil}

Pengujian efektivitas antibakteri dari ekstrak biji kakao terhadap S. pyogenes dilakukan pada media MHA dengan uji difusi cakram (Tabel 1). Percobaan ini dilakukan $5 \times$ pengulangan

Tabel 1. Hasil Pengukuran Zona Hambat Terhadap Pertumbuhan Staphylococcus aureus dalam satuan mm

\begin{tabular}{|c|c|c|c|c|c|c|c|}
\hline \multirow{2}{*}{ Pengulangan } & \multicolumn{7}{|c|}{ Konsentrasi Ekstrak Biji Kakao } \\
\hline & $\mathrm{K}(-)$ & $20 \%$ & $40 \%$ & $60 \%$ & $80 \%$ & $100 \%$ & $\mathrm{~K}(+)$ \\
\hline I & 0 & 7,50 & 9,60 & 10,35 & 8,60 & 10,50 & 15,40 \\
\hline II & 0 & 7,50 & 9,30 & 9,80 & 7,75 & 11,10 & 15,50 \\
\hline III & 0 & 7,65 & 9,10 & 8.70 & 7,85 & 9,40 & 15,50 \\
\hline IV & 0 & 8,85 & 9,40 & 11,20 & 9,30 & 12,65 & 15,65 \\
\hline $\mathrm{V}$ & 0 & 8,85 & 9,25 & $10 ., 0$ & 8,50 & 11,25 & 15,15 \\
\hline Rata-rata & $\mathbf{0}$ & 8,07 & 9,33 & 10,05 & 8,4 & 10,98 & 15.44 \\
\hline
\end{tabular}

Keterangan :

K (-) : Kontrol negatif menggunakan Aquades steril

$\mathbf{K}(+)$ : Kontrol positif menggunakan Antibiotik Ampisilin

Konsentrasi ekstrak biji kakao : perbandingan pengenceran antara ekstrak biji kakao dengan aquades steril

Hasil penelitian (Tabel 1) menunjukkan bahwa ekstrak biji kakao mempunyai efektivitas 
sebagai antibakteri terhadap S. pyogenes, diameter zona hambat terendah terdapat pada konsentrasi $20 \%$ dan diameter zona hambat tertinggi terdapat pada konsentrasi ekstrak $100 \%$, namun tidak melampaui kontrol positif. Terlihat peningkatan diameter zona hambat seiring bertambahnya konsentrasi, namun terlihat penurunan diameter zona hambat saat masuk ke ekstrak dengan konsentrasi $80 \%$. Pada konsentrasi ekstrak $80 \%$, terlihat rata-rata diameter zona hambat yang lebih kecil pada konsentrasi $40 \%$ (diagram 1).

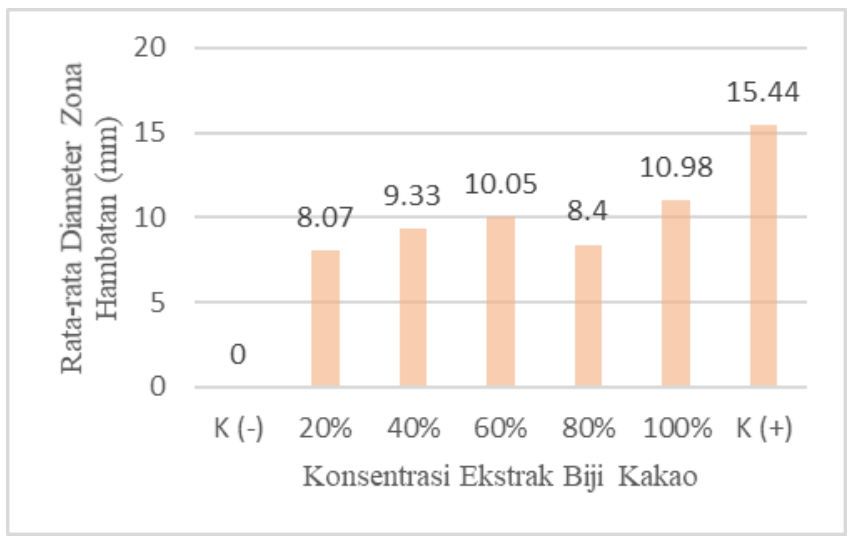

Diagram 1. Hasil Rata-rata Zona Hambat pada Uji Efektivitas Ekstrak Biji Kakao terhadap Pertumbuhan S. pyogenes

Zona hambat terkecil dari semua konsentrasi dan pengulangan, didapatkan diameter sebesar 7,50 mm yang muncul pada konsentrasi $20 \%$ pada pengulangan I dan II. Zona terbesar dari semua konsentrasi dan pengulangan, didapatkan 12,65 mm yang muncul pada konsentrasi $100 \%$ pada pengulangan ke IV.

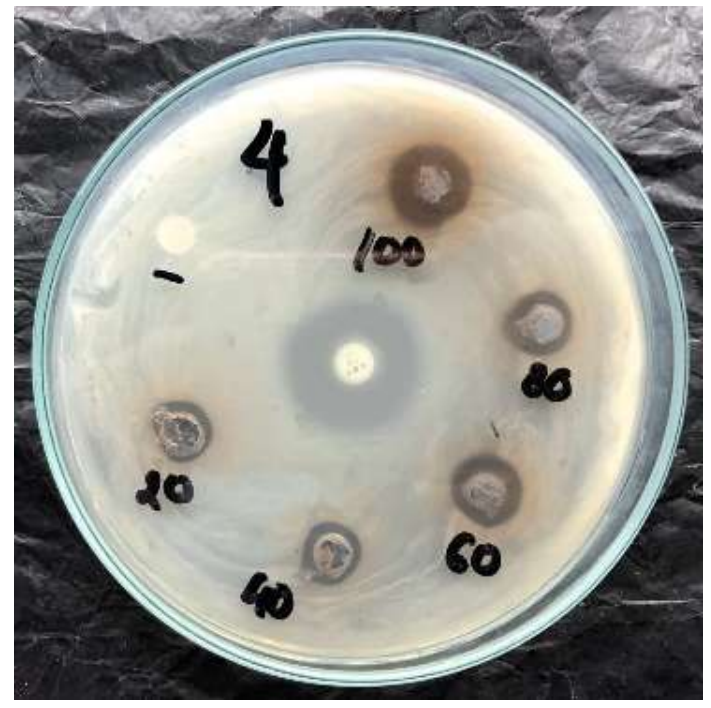

Gambar IV. 1 Hasil Uji Efektivitas Antibakteri Ekstrak Biji Kakao Terhadap Pertumbuhan S. pyogenes

Tabel 2. Hasil Uji One-Way Anova Uji Efektivitas Antibakteri Ekstrak Biji Kakao Terhadap Pertumbuhan S. pyogenes

\begin{tabular}{cccccc} 
Diameter & Jumlah Kuadrat & df & Rata-rata Kuadrat & F & Sig. \\
\hline Diantara Grup & 28.435 & 4 & 7.109 & 11.204 & .000 \\
Dalam Grup & 12.689 & 20 & .634 & & \\
\hline Total & 41.124 & 24 & & &
\end{tabular}

Berdasarkan uji statistik One-Way ANOVA, didapatkan perbedaan yang bermakna dari hasil peningkatan persentase kadar ekstrak kakao yang dapat menghambat pertumbuhan $S$. pyogenes $(\mathrm{p}<0.005)$. 


\section{Pembahasan}

Hasil uji ekstrak biji kakao terhadap pertumbuhan S. pyogenes menunjukkan ekstrak biji kakao efektif menghambat pertumbuhan $S$. pyogenes pada berbagai konsentrasi (Tabel 1). Hal ini berdasarkan aturan Depkes RI (1989) bahwa suatu bahan aktif dapat dikatakan efektif jika bahan aktif tersebut memiliki diameter penghambatan terhadap sebesar $6 \mathrm{~mm}$ atau 0,6 cm. Jika dilihat dari aturan Depkes RI (1989), maka konsentrasi ekstrak biji kakao dalam penelitian ini yang memenuhi syarat dimulai pada konsentrasi $20 \%$ dengan diameter hambatan yang paling kecil $7,50 \mathrm{~mm} .^{13}$

Efektivitas biji kakao sebagai antibakteri terhadap kuman S. pyogenes dikarenakan senyawa aktif alkaloid yang merupakan senyawa organik dengan atom nitrogen dan bersifat basa (alkali). Senyawa ini dapat menyebabkan koagulasi protein yang mengganggu komponen penyusun peptidoglikan pada sel bakteri, sehingga lapisan dinding sel tidak terbentuk secara utuh, dan menyebabkan kematian sel bakteri. ${ }^{14,15}$

Selain senyawa alkaloid, biji kakao juga mempunyai senyawa Flavonoid yang dapat berinteraksi dengan protein membran sel bakteri melalui proses absorbsi dengan cara terikat pada bagian hidrofilik membran sel. Senyawa fenolik masuk ke dalam membran sel menyebabkan presipitasi protein sel yang menyebabkan permeabilitas membran sel terganggu, sehingga membran sel akan mengalami lisis. ${ }^{16,17}$

Penelitian sebelumnya dalam pengujian aktivitas antioksidan dan antimikroba ekstrak kulit konsentrat buah kakao varietas Forastero, menunjukkan bahwa ekstrak kulit buah kakao mempunyai aktivitas antibakteri terhadap E. coli dan S. aureus. Bakteri E. coli mempunyai sifat lebih peka terhadap senyawa aktif ekstrak. Pada penelitian tersebut, konsentrasi ekstrak yang diujikan adalah 5\%, 10\%, dan 20\% dengan menggunakan Dimetil sulfoksida (DMSO) sebagai pengencer ekstrak. Penghambatan bakteri terjadi pada semua konsentrasi ekstrak tersebut. Pelarut DMSO merupakan pelarut polar berspektrum luas, sehingga dapat melarutkan senyawa alkaloid dan flavonoid yang terkandung dalam kulit buah kakao. ${ }^{18}$

Senyawa aktif lain yang memiliki efek antibakteri yaitu tanin. Tanin menginaktifkan adhesin sel bakteri sehingga mengganggu transport protein pada pada lapisan dalam sel. Tanin juga berikatan dengan polipeptida dinding sel bakteri sehingga pembentukan dinding sel menjadi kurang sempurna dan menyebabkan bakteri menjadi lisis. ${ }^{19}$

\section{Kesimpulan}

Ekstrak biji kakao memiliki aktivitas antimikroba terhadap pertumbuhan bakteri Gram positif $S$. pyogenes. Sehingga dapat menjadi alternatif sumber antibiotik baru yang pada saat ini menjadi kekhawatiran jenis antibiotik lama atau baru tidak dapat nenandingi tingkat kecepatan resistensi bakteri-bakteri penyebab penyakit.

\section{DAFTAR PUSTAKA}

1. Kementrian Perencanaan Pembangunan Nasional. Indonesian biodiversity strategy and action plan 2015-2020. Jakarta: Bappenas, 2016.23

2. Bahtera E. Terbesar kedua di dunia, keanekaragaman hayati Indonesia baru tergarap 5\%. Unpad News. sitasi http://news.unpad.ac.id/?p=36173 diakses tanggal 05 Oktober 2019

3. Yunitasari, N. Pemanfaatan daun pandan wangi, jahe, dan biji kapulaga sebagai minuman teh untuk obat herbal antidiabetes. UNES J Scientech Res. 2018; 3(2):197-203

4. Azizah DN, Kumolowati E, Fahrauk F. Penetapan kadar flavonoid metode Alcl3 pada ekstrak metanol kulit buah kakao (Theobroma cacao L.). Kartika: Jurnal Ilmiah Farmasi. 2014; 2(2): 45-9 
5. Ariati SN, Waeniati, Muslimin, Swastika IN. Induksi kalus tanaman kakao (Theobroma cacao L.) pada media MS dengan penambahan 2,4-D, BAP dan air kelapa. J Sci Tech. Desember; 1(1):74-84

6. Arts ICW, Hollman PCH, Kromhout D. Chocolate as a source of tea flavonoids. Lancet J. 1999; 354 (9177): 488

7. Mulyatni AS, Budiani A, Taniwiryono D. Aktivitas antibakteri ekstrak kulit buah kakao (Theobroma Cacao L.) Terhadap Escherichia coli, Bacillus subtilis, dan Staphylococcus aureus. E-Journal Menara Perkebunan. 2012; 80(2), 77-84

8. Yumas M. Pemanfaatan limbah kulit ari biji kakao (Theobroma cacao 1) sebagai sumber antibakteri streptococcus mutans. Jurnal Industri Hasil Perkebunan. 2017;12(2), 7-12

9. Purnamasari DA, Munadziroh E, Yogiartono RM. Konsentrasi ekstrak biji kakao sebagai material alam dalam menghambat pertumbuhan Streptococcus mutans. Jurnal PDGI. 2010; 59(1), 14-8

10. Lamagni TL, Neal S, Keshishian C, Powell D, N Potz, Pebody R, et al. Predictors of death after severe Streptococcus pyogenes infection. Emerg Infect Dis. 2009;15(8):1304-7.

11. Wessels MR, Ferretti JJ, Stevens DL, Fischetti VA. Streptococcus pyogenes: Basic biology to clinical manifestations. University of Oklahoma Health Sciences Center. 2016

12. Davies MR, Holden MT, Coupland P, Chen JHK, Venturini C, Barnett TC, et al. Emergence of scarlet fever Streptococcus pyogenes emm12 clones in Hong Kong is associated with toxin acquisition and multidrug resistance. Nat Genet. 2014; (47): 84-7

13. Departemen Farmakologi dan Terapeutik Fakultas Kedokteran Universitas Indonesia. Farmakologi dan terapi. Edisi 5. Jakarta: Balai Penerbit FK UI. 2007.

14. Aniszewski T. Alkaloids- secrets of life alkaloids chemistry, biological significance application and ecological role. 1st Ed. Amsterdam: Elsevier; 2007

15. Mawan AR, Indriwati SE, Suhadi. Aktivitas antibakteri ekstrak metanol buah Syzygium polyanthum terhadap pertumbuhan bakteri Escherichia coli. Jurnal Bioeksperimen. 2018; 4(1): 66

16. Ramlah S. Karakteristik mutu dan citarasa cokelat kaya polifenol. Jurnal Industri Hasil Perkebunan. 2016; 11(1): 23-32

17. Kayaputri IL, Sumanti DM, Djali M, Indiarto R, Dewi DL. Kajian fitokimia ekstrak kulit biji kakao (Theobroma cacao L.). J Chimica et Natura Acta. 2014; 2(1): 83-90

18. Sartini, Djide MN, Alam G. Ekstraksi komponen bioaktif dari limbah kulit buah kakao dan pengaruhnya terhadap aktivitas antioksidan dan antimikroba. Diunduh dari: [http://mot.f armasi. ugm.ac.id/files/18kulitaacao_PakAlam.pdf], 5 Oktober 2019

19. Ngajowa M, Abidjulua J, Kamu V. Pengaruh antibakteri ekstrak kulit batang matoa (Pometia pinnata) terhadap bakteri Staphylococcus aureus secara In vitro. Jurnal Mipa Unsrat. 2013; 2(2): 128-32 